\title{
Pendekatan Pragmatik dalam Mendukung Kemampuan Komunikasi Lisan
}

\begin{abstract}
Saefudin $^{1}$
Abstrak

Tujuan dari komunikasi adalah untuk mendapatkan pesan dari orang lain secara jelas dan tidak ambigu. Melakukan komunikasi memerlukan usaha dari pengirim maupun penerima. Proses komunikasi dapat terganggu dengan adanya kesalahan, sehingga pesan akhirnya disalahtafsirkan oleh penerima. Ketika gangguan tersebut tidak terdeteksi, hal ini dapat menimbulkan kebingungan, usaha yang sia- sia dan kesempatan yang hilang. Kenyataannya, Komunikasi akan sukses bila kedua pihak memahami informasi yang sama sebagai hasil dari komunikasi. Jadi, dapat diasumsikan bahwa pendekatan yang dapat menciptakan situasi pembelajaran bahasa kedua (asing), terutama dalam kemampuan komunikasi lisan adalah dalam bentuk pragmatic. Tulisan ini mencoba membahas alasan mengapa ada nilai dalam pembelajaran pragmatic secara eksplisit pada pembelajar bahasa kedua (L2) dalam target bahasa. Pentingnya isu dalam gagasan pragmatic sangat dipertimbangkan, termasuk dalam menentukan kontribusi pragmatic dalam mendukung kemampuan berbicara siswa, bagaimana mempersiapkan pembelajar bahasa dalam memahami hubungan pragmatic dan fungsi bahasa dalam terma komunikasi yang dapat diterima, dan peranan sintaksis dan semantic dalam mem fasilitasi pembelajaran pragmatik
\end{abstract}

Kata Kunci: Pragmatik, pendekatan komunikatif, dan fungsi bahasa

\begin{abstract}
The purpose of communication is to get the message across to others clearly and unambiguously. Doing this involves effort from both the sender of the message and the receiver. And it's a process that can be fraught with error, with messages often misinterpreted by the recipient. When this isn't detected, it can cause tremendous confusion, wasted effort and missed opportunity. In fact, communication is only successful when both the sender and the receiver understand the same information as a result of the communication. So, it is assumed that the approach which can creat the situation of second language learning, especially oral communication skill is pragmtics. This paper discusses a rationale why there is value in explicitly learning pragmatics for second-language (L2) learners in the target language. The importance of issues in the notion of pragmatics is considered, including determining the contribution of pragmatics in supporting the students' speaking skill, how to preapre the language learners understand the relation of pragmatics and language functions in the term of acceptable communication, and the role of syntax and semantics in facilitating the learning of pragmatics.
\end{abstract}

Keywords: Pragmatics, Communicative approach, and Language Functions,

\footnotetext{
${ }^{1}$ Fakultas Adab dan Humaniora, Universitas Islam Negeri (UIN) Syarif Hidayatullah Jakarta
} 


\section{A. Pendahuluan}

Target utama dalam melakukan komunikasi lisan sesungguhnya adalah bagaimana penutur mampu memahami budaya para lawan bicaranya, khususnya dalam kerangka cara berfikir, pola hidup, etos kerja, serta kepercayaan yang di anut, sehingga pada gilirannya penutur bahasa tersebut mempu menggunakan bahasa sesuai dengan aturan sosial yangberlaku. Artinya, ketika kita sedang berbicara dengan orang lain kita harus memperhatikan setting atau konteks pembicaraan yang meliputi; dengan siapa, kapan, dan di mana kita berbicara. Oleh sebab itu, analisis percakapan (conversation analysis) memandang tindakan empiris para penutur. $^{2}$

Dalam jangka waktu yang cukup lama, seperti diungkap oleh Yule (1996:6), studi bahasa sangat dikuasai oleh kecenderungan untuk menjelaskan bahasa berdasarkan sistem formalnya, yaitu dengan menurunkan sistem yang terdapat dalam matematika dan logika, dan mengabaikan unsurpengguna bahasa. Sebagai tataran terbaru dalam linguistik, Pragmatik merupakan satu- satunya tataran yang turut mem- perhitungkan manusia sebagai pengguna bahasa. Meskipun memiliki fokus kajian yang serupa dengan semantik, yaitu makna, seperti akan dijelaskan kemudian, makna yang dikaji dalam pragmatik berbeda dengan makna yang dikaji dalam semantik.

Dalam kajian pragmatik yang paling penting adalah bagaimana bahasa itu berterima (appropriateness). Oleh karena itu keberterimaan dalam berbahasa seharusnya disadari oleh pembelajar bahasa sejak dini yang menekankan pada kegiatan sehari-hari, mulai dengan konteks lokal. Termasuk dalam pembelajaran bahasa asing, para pembelajar harus diajarkan untuk menggunakan bahasa yang dia pelajari, mulai dari situasi kehidupan nyata sehari-hari yang dia alami. Hal ini sebenarnya sudah

${ }^{2}$ Deborah Schffin, 1994. Approach to Discourse (Cambirdge: Blackwell Publisher), hal. 236. tercermin dalam kurikulum berbasis kompetensi. $^{3}$

Jadi, pada prinsipnya bahwa keterampilan berbicara harus didukung oleh pemahaman penutur tentang teori pragmatik, begitu juga penutur harus memahami teori tentang bahasa komunikatif dimana bahasa yang digunakan harus mengacu pada ekspresi-ekspresi fungsional yang biasa digunakan oleh penutur asli (native speaker). Dikatakan oleh Brown bahwa tujuan akhir dari pendekatan komunikatif adalah mampu berkomunikasi dengan penutur asli. Yang menjadi fokus perhatian dalam pembelajarannya adalah keterampilan berbicara dan menyimak, menulis untuk tujuan komunikasi khusus, dan membaca teks asli. ${ }^{4}$ Dan diakui bahwa yang mendasari gerakan pengajaran bahasa komunikatif (CLT) ini adalah prinsip- prinsip yang penting dari teori tingkah laku bahasa (language behavior).

\section{B. Pembahasan}

\section{Pengertian}

Pragmatik adalah studi tentang makna ungkapan-ungkapan linguistik dalam kontek. ${ }^{5}$ Pragmatik mempunyai kaitan yang sangat erat dengan penggunaan bahasa (language use) secara fungsional. Para pakar pragmatic mendefinisikan istilah ini secara berbeda-beda. Yule, misalnya, menyebutkan empat definisi pragmatik, yaitu (1) bidang yang mengkaji makna pembicara; (2) bidang yang mengkaji makna menurut konteksnya; (3) bidang yang, melebihi kajian tentang makna yang diujarkan, mengkaji makna yang dikomunikasikan atau terkomunikasikan oleh pembicara; dan (4) bidang yang mengkaji bentuk ekspresi menurut jarak sosial yang membatasi

\footnotetext{
${ }^{3}$ Bandingkan: Kurikulum Bahasa Inggris Tahun 2004 untuk SD, SMP, dan SMA

${ }^{4} \mathrm{H}$. Doughlas Brown, 1987. Principle of Language Learning and Teaching (USA.: Prentice Hall, Second dition), hal. 198.

${ }^{5}$ Ibid., p. 59.
} 
partisipan yang terlibat dalam percakapan tertentu. $^{6}$

Thomas menyebut dua kecen- derungan dalam pragmatik terbagi menjadi dua bagian, pertama, dengan menggunakan sudut pandang sosial, menghubungkan pragmatik dengan makna pembicara (speaker meaning); dan kedua, dengan menggunakan sudut pandang kognitif, menghubungkan pragmatik dengan interpretasi ujaran (utterance interpretation). ${ }^{7} \quad$ Selanjutnya Thomas dengan mengandaikan bahwa pemaknaan merupakan proses dinamis yang melibatkan negosiasi antara pembicara dan pendengar serta antara konteks ujaran (fisik, sosial, dan linguistik) dan makna potensial yang mungkin dari sebuah ujaran ujaran, mendefinisikan pragmatik sebagai bidang yang mengkaji makna dalam interaksi (meaning in interaction). ${ }^{8}$

Leech (dalam Gunarwan) melihat pragmatik sebagai bidang kajian dalam linguistik yang mempunyai kaitan dengan semantik. Keterkaitan ini ia sebut semantisisme, yaitu melihat pragmatik sebagai bagian dari semantik; prag- matisisme yaitu melihat semantik sebagai bagian dari pragmatik; dan komplementarisme, atau melihat semantik dan pragmatik sebagai dua bidang yang saling melengkapi. $^{9}$

Teori pragmatik dan tentu saja keterampilan pragmatik, kata Sudiati dan Widyamarta dapat memberikan bekal akan berbagai kemungkinan strategi di dalam berkominikasi, pemerkayaan kemampuan menggunakan bahasa di dalam berbagai macam situasi. Belajar pragmatik adalah 'belajar agar dapat berbahasa

\footnotetext{
${ }^{6}$ George Yule. Pragmatics. (Oxford: Oxford university Pres, 1996), hal. 3

7 Jenny Thomas. 1995. Meaning in Interaction: an Introduction to Pragmatics. ( London/New York: Longman), hal. 2.

${ }^{8}$ Ibid. hal. 22

${ }^{9}$ Asim Gunarwan. Pragmatik, Teori dan Kajian Nusantara. (Jakarta: Univ. Atmajaya Press, 2007), hal. 2.
}

dengan enak dan mudah, tidak hanya dalam forum tak resmi, tetapi juga di dalam forum formal. ${ }^{10}$ Sedangkan tujuan pragmatik sendiri adalah mengoptimalkan komunikasi dengan bahasa.

Agar bahasa yang digunakan dalam komunikasi betul-betul komunikatif, bentuk-bentuk bahasa harus disesuaikan dengan situasi bahasa. Dalam berko- munikasi, tidak hanya dituntut kesamaan gagasan antara pembicara dan pendengar, tetapi juga dituntut keenakan perasaan antara kedua belah pihak. Keenakan perasaan apabila kedua belah pihak menyelaraskan diri dan bahasanya dengan situasi. Situasi dimaksud meliputi faktorfaktor berikut ini:

1. Siapa berbahasa tentang apa dengan siapa?

2. Apa tujuannya?

3. Bagaimana keadaannya (waktu dan tempatnya)?

4. Bagaimana pula konteksnya (pesertapeserta yang lain, kebudayaan, dan suasana)?

5. Dengan jalur mana?

6. Apa medianya (tatap muka, telepon, surat, telegram, Koran, buku, majalah, dan sebagainya)?

7. Dalam peristiwa (percakapan, ceramah, upacara, laporan, lamaran kerja, pernyataan cinta, dan sebagainya)?

Jadi, di sini dapat ditegaskan bahwa keterampilan pragmatik adalah kemampuan berkomunikasi dengan bahasa, yaitu keterampilan menggunakan bahasa yang sesuai, selaras, dan serasi dengan faktor-faktor situasi itu. Pemilihan kata, pembentukan frase, penyusunan kalimat dengan panjang- pendeknya, penyusunan alinea dengan panjangpendeknya (dalam wacana tulis), dan segi-segi bahasa yang lain, semuanya perlu diterapkan menurut situasinya.

\section{Perkembangan Pragmatik}

10 V. Sudiati dan A. Widyamarta, 1996. Kreatif Berbahasa Menuju Keterampilan Pragmatik (Yoyakarta: Kanisius), hal. 7. 
Dalam persepektif historis bahwa pragmatic telah tumbuh di Eropa pada 1940-an dan berkembang di Amerika sejak tahun 1970-an. Morris (1938) dianggap sebagai peletak tonggaknya lewat pandangannya tentang semiotik. Ia membagi ilmu tanda itu menjadi tiga cabang: sintaksis, semantik, dan pragmatik. Kemudian Halliday (1960) yang berusaha mengembangkan teori social mengenai Bahasa yang memandang bahasa sebagai fenomena sosial

Di Amerika, karya filsuf Austin (1962) dan muridnya Searle (1969, 1975), banyak mengilhami perkembangan pragmatik. Karya Austin yang dianggap sebagai perintis pragmatik berjudul How to Do Things with Words (1962). Dalam karya tersebut, Austin mengemukakan gagasannya mengenai tuturan performatif dan konstatif. Gagasan penting lainnya adalah tentang tindak lokusi, ilokusi, perlokusi dan daya ilokusi tuturan.

Beberapa pemikir pragmatik lainnya, yaitu: Searle (1969) me- ngembangkan pemikiran Austin. Ia mencetuskan teori tentang tindak tutur yang dianggap sangat penting dalam kajian pragmatik. Tindak tutur yang tidak terbatas jumlahnya itu dikategorisasikan berdasarkan makna dan fungsinya menjadi lima macam, yaitu: representatif, direktif, ekspresif, komisih, dan deklaratif.

Grice (1975) mencetuskan teori tentang prinsip kerja sama (cooperative principle) dan implikatur percakapan (conversational implicature). Menurut Grace, prinsip kerja sama adalah prinsip percakapan yang membimbing pesertanya agar dapat melakukan percakapan secara kooperatif dan dapat menggunakan bahasa secara efektif dan efisien. Prinsi ini terdiri atas empat bidal: kuantitas, kuaitas, relasi, dan cara. Menurut Gunarwan (1994: 54), keunggulan teori prinsip kerja sama ini terletak pada potensinya sebagai teori inferensi apakah yang dapat ditarik dari tuturan yang bidal kerja sama itu.
Keenan (1976) menyimpulkan bahwa bidal kuantitas, yaitu "buatlah sumbangan Anda seinformatif-infor- matifnya sesuai dengan yang diper- lukan". Hal ini berdasarkan penelitian tentang penerapan prinsip kerja sama di masyarakat Malagasi. Goody (1978) menemukan bahwa pertanyaan tidak hanya terbatas digunakan untuk meminta informasi, melainkan juga untuk menyuruh, menandai hubungan antar- pelaku percakapan, menyatakan dan mempertanyakan status.

Fraser (1978) telah melakukan deskripsi ulang tentang jenis tindak tutur. Gadzar (1979) membicarakan bidang pragmatic dengan tekanan pada tiga topik yaitu: implikatur praanggapan, dan bentuk logis. Gumperz (1982) me- ngembangkan teori implikatur Grizer dalam bukunya Discourse Strategies. Ia berpendapat bahwa pelanggaran atas prinsip kerja sama seperti pelanggaran bidal kuantitas dan cara menyiratkan sesuatu yang tidak dikatakan. Sesuatu yang tidak diekspresikan itulah yang dinamakan implikatur percakapan.

Levinson (1983) mengemukakan revisi sebagai uapaya penyempurnaan pendapat Grize tentang teori implikatur. Leech (1983) mengemukakan gagasannya tentang prinsip kesantunan dengan kaidah yang dirumuskannya ke dalam enam bidal: ketimbangrasaan, kemurahhatian, keperkenanan, kerendahhatian, kesetujuan, dan kesimpatian. Mey (1993) mengemukakan gagasan baru tentang pembagian pragmatik: mikropragmatik dan makropragmatik.

Schiffrin (1994) mambahas berbagai kemudian kajian wacana dengan menggunakan pendekatan pragmatik. Yule (1996) mengembangkan teori tentang PKS dengan menghubungkannya dengan keberadaan tamengan (hedges) dan tuturan langsung- tuturan tak langsung. Teun van Dijk (1998-2000) mengembangkan model analisis wacana kritis (Critical Discourse Analysis/ CDA) di dalam teks berita. Ia mengidentifikasi adanya lima karakteristik yang harus dipertimbangkan di dalam 
CDA, yaitu: tindakan, konteks, historis, kekuasaan dan ideologi.

\section{Pragmatik Dan Semantik}

Cruse mengatakan "Meaning makes little sense except in the context of communication: the notion of communication therefore provides asgood a place as any to start an exploration of meaning." 11 Oleh sebab itu ketika belajar bahasa maka diharapakan pembelajar mampu memahami makna secara semantik lebihlebih secara pragmatik.

Kata semantik berasal dari bahasa Yunani sema yang artinya tanda atau lambang (sign). "Semantik" pertama kali digunakan oleh seorang filolog Perancis bernama Michel Breal pada tahun 1883 . Kata semantik kemudian disepakati sebagai istilah yang digunakan untuk bidang linguistik yang mempelajari tentang tanda-tanda linguistik dengan hal-hal yang ditandainya. Oleh karena itu, kata semantik dapat diartikan sebagai ilmu tentang makna atau tentang arti, yaitu salah satu dari tiga tataran analisis bahasa: fonologi, gramatika, dan semantik (Chaer, 1994: 2).

Sementara itu pragmatik memu- satkan perhatian pada penggunaan bahasa dalam kalangan penutur berdasarkan konteks sesuatu peristiwa pertuturan. Sedangkan perbedaan prinsip

dari kedua studi makna tersebut dapat dilihat di bawah ini.

a. Semantik mempelajari makna, yaitu makna kata dan makna kalimat, sedangkan pragmatik mempelajari maksud ujaran, yaitu untuk apa ujaran itu dilakukan.

b. Kalau semantik bertanya "Apa makna $X$ ?" maka pragmatik bertanya "Apa yang Anda maksudkan dengan X?"

c. Makna di dalam semantik ditentukan oleh koteks, sedangkan makna di dalam pragmatik ditentukan oleh konteks, yakni siapa yang berbicara,

${ }^{11}$ Alan Crues. 2000. Meaning in Language: an Introduction to Semantics and Pragmatics (New York: Oxford University Press), hal. 5. kepada siapa, di mana, bilamana, bagaimana, dan apa fungsi ujaran itu. Berkaitan dengan perbedaan (c) ini, Kaswanti Purwo (1990: 16) merumuskan secara singkat "semantik bersifat bebas konteks (context independent), sedangkan pragmatic bersifat terikat konteks (context dependent)" (bandingkan Wijana,1996: 3).

Menurut Leech (dalam Eelen) perbedaan antara semantik dan pragmatik pada, pertama, semantik mengkaji makna (sense) kalimat yang bersifat abstrak dan logis, sedangkan pragmatik mengkaji hubungan antara makna ujaran dan daya (force) pragmatiknya; dan kedua, semantik terikat pada kaidah (rulegoverned), sedangkan pragmatik terikat pada prinsip (principle-governed). Tentang perbedaan yang pertama, meskipun makna dan daya adalah dua hal yang berbeda, keduanya tidak dapat benar-benar dipisahkan, sebab daya mencakup juga makna. Dengan kata lain, semantik mengkaji makna ujaran yang dituturkan, sedangkan pragmatik mengkaji makna ujaran yang terkomunikasikan atau dikomunikasikan. Selanjutnya, kaidah berbeda dengan prinsip berdasarkan sifatnya. Kaidah bersifat deskriptif, absolut atau bersifat mutlak, dan memiliki batasan yang jelas dengan kaidah lainnya, sedangkan prinsip bersifat normatif atau dapat diaplikasikan secara relatif, dapat bertentangan dengan prinsip lain, dan memiliki batasan yang bersinggungan dengan prinsip lain ${ }^{12}$

Pembahasan makna dalam semantik belum memadai, karena masih mengabaikan unsur pengguna bahasa, sehingga bentuk seperti seandainya 'saya dapat berdiri tentu saya tidak akan dapat berdiri dan saya akan datang besok pagi', meskipun bentuk seperti ini dapat saja kita jumpai, tidak dapat dinyatakan benar karena yang pertama menyalahi logika dan yang kedua tidak dapat diverifikasi langsung. Dengan kata lain, untuk

\footnotetext{
${ }^{12}$ Gino Eelen, 2001. Critique of Politeness Theory.
} (U.K: Northampton, MA : St. Jerome), hal. 6 
menjelaskan fenomena pemakaian bahasa sehari-hari, di samping sintaksis dan semantik, dibutuhkan juga pragmatik yang dalam hal ini dipahami sebagai bidang yangmengkaji hubungan antara struktur yang digunakan penutur, makna apa yang dituturkan, dan maksud dari tuturan. Kegunaan pragmatik, yang tidak terdapat dalam sintaksis dan semantik, dalam hal ini dapat ditunjukkan dengan, misalnya, bagaimana strategi kesantunan mempengaruhi penggunaan bahasa, bagaimana memahami implikatur percakapan, dan bagaimana kondisi felisitas yang memungkinkan bagi sebuah tindak-tutur.

Lebih jauh lagi, dalam pengajaran bahasa, seperti diungkapkan Gunarwan (2004: 22), terdapat keterkaitan, yaitu bahwa pengetahuan pragmatik dalam arti praktis, patut diketahui oleh pengajar untuk membekali pemelajar dengan pengetahuan tentang penggunaan bahasa menurut situasi tertentu. Dalam pengajaran bahasa Indonesia, misalnya, pengetahuan ini penting untuk membimbing pemelajar agar dapat menggunakan ragam bahasa yang sesuai dengan situasinya, karena selain benar, bahasa yang digunakan harus baik. Dalam pengajaran bahasa asing, pengetahuan tentang prinsip-prinsip pragmatik dalam bahasa yang dimaksud penting demi kemampuan komunikasi yang baik dalam bahasa tersebut. Secara umum, dapat disimpulkan bahwa kaitan antara pragmatik dan pengajaran bahasa adalah dalam hal kompetensi komunikatif yang mencakup tiga macam kompetensi lain selain kompetensi gramatikal (grammatical competence), yaitu kompetensi sosiolinguistik (sociolinguistic competence) yang berkaitan dengan pengetahuan sosial budaya bahasa tertentu, kompetensi wacana (discourse competence) yang berkaitan dengan kemampuan untuk menuangkan gagasan secara baik, dan kompetensi strategik (strategic competence) yang berkaitan dengan kemampuan pengungkapan gagasan melalui beragam gaya yang berlaku khusus dalam setiap bahasa. ${ }^{13}$

\section{Pragmatik Dan Fungsi Bahasa}

Bidang "pragmatik" dalam linguistik dewasa ini mulai mendapat perhatian para peneliti dan pakar bahasa, termasuk di Indonesia. Bidang ini cenderung mengkaji fungsi ujaran atau fungsi bahasa daripada bentuk atau strukturnya. Dengan kata lain, pragmatik lebih cenderung ke fungsionalisme daripada ke formalisme. Hal itu sesuai dengan pengertian pragmatik yang dikemukakan oleh Levinson bahwa pragmatik adalah kajian mengenai penggunaan bahasa atau kajian bahasa dan perspektif fungsonal. Artinya, kajian ini mencoba menjelaskan aspek- aspek struktur bahasa dengan mengacu ke pengaruh-pengaruh dan sebab-sebab non bahasa. ${ }^{14}$

Fungsi bahasa yang paling utama adalah sebagai sarana komunikasi. Di dalam komunikasi, satu maksud atau satu fungsi dapat dituturkan dengan berbagai bentuk tuturan. Misalnya, seorang guru yang bermaksud menyuruh muridnya untuk mengambilkan kapur di kantor, dia dapat memilih satu di antara tuturan- tuturan berikut:

(1) Take me a chalk!

(2) No chalk here.

(3) I need a chalk.

(4) Oh, this class has no chalk, right?

(5) There is no chalk, isn't ther?

(6) Why doesn't one of you bring me a chalk?

Dengan demikian untuk maksud "menyuruh" agar seseorang melakukan suatu tindakan dapat diungkapkan dengan menggunakan kalimat imperatif seperti tuturan (1), kalimat deklaratif seperti tuturan (2-4), atau kalimat interogatif seperti tuturan (5-6). Jadi, secara pragmatis, kalimat berita (deklaratif) dan kalimat tanya (interogatif) di samping berfungsi untuk memberitakan atau menanyakan

\footnotetext{
${ }^{13}$ Asim Gunarwan, Op. Cit., hal. 22.

${ }^{14}$ Levinson, S.C. 1983. Pragmatics. (Cambridge: Cambridge University Press), hal. 5-7.
} 
juga berfungsi untuk menyuruh(imperatif atau direktif).

Dalam bukunya Principles of Language Learning and Teaching, Brown mengatakan bahwa pada akhir abad ke 20, tepatnya tahun 1980 dicirikan munculnya gelombang baru terhadap minat untuk mempelajari bahasa kedua atau asing dengan menggunakan pendekatan komunikatif. Tujuan akhir dari pendekatan ini adalah mampu berkomunikasi dengan penutur asli. Yang menjadi fokus perhatian dalam mebelajarannya adalah keterampilan berbicara dan menyimak, menulis untuk tujuan komunikasi khusus, dan membaca teks asli. Dan diakui bahwa yang mendasari gerakan pengajaran bahasa komunikatif ini adalah prinsip prinsip yang penting dari teori tingkah laku bahasa (language behavior). ${ }^{15}$

Hal ini berarti pembelajaran bahasa mengacu pada penggunaan bahasa secara fungsional dan bahkan alamiah. Oleh sebab itu, informasi mengenai sosio- linguistik penutur asli sangat penting untuk difahami oleh siswa, sehingga diharapkan siswa betul-betul mengetahui bagaimana menggunakan fungsi-fungsi bahasa itu serta aturan-aturan budaya kapan, di mana dan dengan siapa bahasa itu boleh digunakan secara tepat. Kemampuan untuk menyampaikan dan menafsirkan pesan serta untuk mene- gosiasikan makna secara interpersonal dalam kontek yang positif oleh Hymes (1967) disebut sebagai kompetensi komunikatif (communicative comptence). Sedangkan menurut Savignon (1983) bahwa kompetensi komunikatif itu relatif, tidak absolut, dan tergantung pada semua partisipan yang terlibat. ${ }^{16}$

Definisi kompetensi komunikatif berikutnya disampaikan oleh Canale (1990) dan Swain $(1980,1983)$, menurutnya bahwa konsep (construct) kompetensi komunikatif tersusun dari empat komponen atau subkategori, yakni kom-

\footnotetext{
${ }^{15}$ Brown, Douglas, Op.Cit., hal. 198

${ }^{16}$ Ibid., hal. 199.
}

petensi gramatika, kompetensi wacana, kompetensi sosiolinguistik dan kompotensi strategi. Kemudian menurut Bachman (1987) kompetensi komunikatif (strategic competence) merujuk pada strategi yang dimiliki komunikator untuk memulai, menghentikan, mempertahankan, memperbaiki, dan meluruskan kembali komunikasi berbahasa seseorang.

Menurut Azis dan Alwasilah bahwa konsep kemahiran berbahasa (language proficiency) itu berbeda dengan konsep kompetensi gramatika (grammatical competence) dan komunikatif dalam beberapa hal, yakni :

a. Konsep kemahiran berbahasa ditafsirkan tidak berdasarkan pengetahuan atau kompetensi, tetapi berdasarkan kepada performansi, yaitu bagaimana bahasa itu digunakan.

b. Konsep kemahiran berbahasa ditafsirkan berdasarkan situasi, tujuan tugas dan aktifitas komunikatif tertentu, seperti menggunakan percakapan untuk interaksi langsung, mendengarkan ceramah, atau membaca buku teks perguruan tinggi.

c. Konsep kemahiran berbahasa merujuk kepada tingkat keterampilan dalam melaksanakan tugas, yaitu merujuk pada nosi keefektifan.

d. Konsep kemahiran berbahasa merujuk kepada kemampuan menggunakan berbagai komponen sub-keterampilan (seperti untuk memilih aspek kompotensi gramatika dan komunikatif yang berbeda beda) agar bisa melaksanakan jenis-jenis tugas yang berbeda pada tingkat keefektifan yang berbedabeda. ${ }^{17}$

Dengan memahami konsep kompetensi komunikatif, baik yang disampaikan oleh Hymes, maupun oleh Canal dan Swain di atas, lebih-lebih kalau sampai mampu memahami konsep kemahiran berbahasa seperti yang diuraikan oleh Bachman, maka tujuan belajar bahasa Inggris bukan sekedar ingin menguasai

\footnotetext{
${ }^{17}$ A. Chaedar Alwasilah, Linguistik Suatu Pengantar (Bandung : Angkasa, 1987), hal. 27.
} 
bentuk-bentuk linguistiknya, namun lebih dari itu bagaimana penguasaan terhadap bentuk- bentuk linguistik tadi bisa dipergunakan untuk melakukan fungsifungsi bahasa yang komunikatif. Artinya, penguasaan terhadap kosakata dan struktur gramatika tidak berarti apa-apa jika pembelajar tidak mampu menerapkannya untuk tujuan komunikasi yang fungsional.

Tujuan ini meliputi: menyampaikan dan menerima fikiran, gagasan dan perasaan diantara penutur dan pendengar untuk bahasa lisan, atau penulis dan pembaca untuk bahasa tulisan. Adapun hubungan antara bentuk (forms), fungsi (functions) dan pragmatik (prafmatic) seperti dijelaskan Brown adalah bahwa bentuk merupakan perwujudan dari bahasa, fungsi adalah realisasi dari bentuk tersebut, dan tujuan pragmatik bahasa (yakni penggunaan kode-kode untuk berkomunikasi) merupakan tujuan akhir dari pembelajar bahasa kedua atau asing. ${ }^{18}$ Begitu pentingnya fungsi-fungsi bahasa dalam wacana kompetensi komunikatif, maka istilah 'functions' selalu menjadi bahan perhatian para ahli linguistik dalam setiap pembicaraan mengenal pemerolehan Bahasa kedua atau asing.

Istilah 'functions' ini pertama kali diperkenalkan oleh ahli linguistik Inggris yang bernama J.R. Firth, dan sejak itu istilah 'functions' diinterpretasikan bermacam-macam. Michael Halliday disebut-sebut sebagai ahli sosiolinguistik yang dianggap paling tepat dalam memberikan pengertian 'fungsi bahasa' sebagai sifat atau ciri komunikasi yang bertujuan (purposive). Menurut Halliday setidaknya ada tujuh fungsi bahasa, seperti yang sudah disinggung sebelumnya, yang pada umumnya dijalankan pada bahasa, yaitu :

1) Fungsi instrumental, menggunakan bahasa untuk memperoleh sesuatu.
2) Fungsi regulatory, menggunakan bahasa untuk mengontrol perilaku orang lain.

3) Fungsi interaksional, menggunakan bahasa untuk menciptakan interaksi dengan orang lain.

4) Fungsi personal, menggunakan bahasa untuk mengungkapkan perasaan dan makna.

5) Fungsi heuristik, menggunakan bahasa untuk belajar dan menemukan makna.

6) Fungsi imajinatif, menggunakan bahasa untuk menciptakan dunia imajinatif.

7) Fungsi representasional menggunakan bahasa untuk menyampaikan informasi. ${ }^{19}$

Halliday (1976) membuat klasifikasi fungsi-fungsi bahasa atas dasar observasi yang terus menerus terhadap penggunaan bahasa oleh anakanaknya sendiri. Atas dasar tujuh fungsi bahasa yang biasa digunakan oleh anakanak cenderung dapat dikembangkan menjadi berbagai fungsi lain yang hampir tidak terbatas jumlahnya yang kita gunakan melalui bahasa. Taksonomi yang dibuat Van Ek dan Alexander (1975) misalnya, memuat sekitar 70 fungsi berbeda untuk diajarkan dalam kurikulum bahasa Inggris.

Kemudian, Van Ek sendiri memuat daftar fungsi-fungsi bahasa yang dibe- dakannya ke dalam enam kategori yang biasa digunakan dalam komunikasi verbal atau keterampilan berbicara:

1) Imparting and seeking information (memberikan dan mencari informasi)

2) Expressing and finding out emotional attitudes (menggunakan dan memahami sikap intelektual)

3) Expressing and finding out emotional attitudes (mengungkapkan dan mema- hami sikap emosional) 
4) Expressing and finding out moral attitudes (mengungkapkan dan me- mahami sikap moral)

5) Getting things done (mengusahakan agar sesuatu dapat dikerjakan/suasion).

6) Socialising (untuk bergaul sebagai anggota masyarakat). ${ }^{20}$

Masing-masing diantara enam kategori atau (enam fungsi bahasa) tersebut diwujudkan secara terpisah dalam bentuk tindak bahasa (language act). Akan tetapi sering sekali dua fungsi atau lebih menurut pendapat Brown bergabung sekaligus dalam satu tindak bahasa. Jadi, pada saat yang bersamaan seseorang bisa saja sambil mencari informasi (seeking information) sekaligus mengungkapkan rasa heran (sikap emosional).

Kemampuan komunikatif penutur asli sebagai suatu model menurut Van Ek di atas sebenarnya merupakan perpaduan antara enam kompetensi, yang menyatu dalam tanggungjawab pribadi (autonomy) dan sosial. Enam kom- petensi tersebut meliputi: linguistic competence, sociolinguistic competence, discourse competence, strategic competence, socio-cultural competence, dan social competence.

Linguistic competence diartikan sebagai kemampuan untuk menghasilkan dan menginterpretasikan ujaran yang bermakna, sosiolinguistic competence mencakup hubungan antara simbol- simbol linguistik dan makna yang sesuai dengan kontek dan situasinya, discourse competence adalah kemampuan meng- gunakan strategi yang tepat untuk mengkonstruksikan dan menginterpretasikan text, strategic compe-tence adalah cara-cara yang digunakan untuk menanggulangai kesulitan dalam berkomunikasi, socio-cultural compe- tence merupakan kemampuan untuk membedakan kontek sosio-budaya bahasa yang dipelajari dengan budaya bahasa pembelajar, dan social competence

${ }^{20}$ Brumfit, C.J., and Johnson, K. (Ed). The Communicative Approach to Language Teaching (London: Oxford University Press, 1983), hal, 13. mencakup kemauan (will) dan keterampilan (skill) untuk berinteraksi dengan orang lain, yang meliputi motivasi, sikap, kepercayaan diri, rasa empati dan kemampuan untuk menangani situasi social. $^{21}$ Di sini Van Ek menganjurkan agar para pembelajar berbicara dan menulis sesuai dengan aturan-aturan bahasa yang buruk. Disamping itu, para pembelajar juga perlu menguasai ujaran-ujaran untuk mengungkapkan makna konven- sionalnya, misalnya makna yang diungkapkan oleh penutur asli yang terkait pada ujarannya yang diucapkan secara normal.

Lebih jauh Payatos mengiden- tifikasikan sepuluh dimensi dalam komunikasi dimana pelajar mungkin akan mengalami kesulitan, yakni fonetik, morfologi sintaksis, kosakata, para linguistik (paralanguage; membunyikan lidah, kenyaringan suara yang bermakna dan bisikan), kinesik (kinesics, gerakan komunikatif, sikap dan postur, proksemik (proxenics, jarak pribadi atau keakraban diantara teman, orang tua, kenalan), chemical/dermal (tumpahan air mata, merah muka), adaptasi badan atau obyek (kosmetik, pakaian, artifak pekerjaan) lingkungan yang dibangun dan dimodifikasi (benda-benda yang berstatus, seperti rumah dan taman). Empat yang pertama dari dimensi tersebut merupakan hal yang sudah bisa diajarkan oleh guru bahasa sebagai unsur-unsur di dalam bahasa, tetapi menurut Poyatos tidak cukup sebagai landasan atau dasar dalam komunikasi antar budaya (intercultural communication). Oleh karena itu para guru bahasa harus pula konsen pada unsur- unsur di luar bahasa dengan apa yang disebutnya sebagai "triple reality of speech (language, paralanguage dan kinesics)". ${ }^{22}$

Sehubungan dengan pengajaran bahasa, Poyatos berasumsi bahwa komunikasi non-verbal (paralanguage, kinesics, proksemik, chemical/dermal, body adopters/object-adopters dan built and

\footnotetext{
${ }^{21}$ Michael Byram, Teaching and Assessing Intercultural Communicative Competence (Great Britain: WBC Book Manufactures Ltd., 1997), hal, 10.

${ }^{22}$ Ibid.hal. 13-14.
} 
modified environment) sebenarnya dapat diajarkan kepada siswa, bersama- sama atau terpisah dengan komunikasi verbal. Payatos melihat bahwa kesulitan dalam belajarnya adalah meliputi upaya mengurangi pengaruh (interferensi) dari sistem nonverbal bahasa asli pembelajar supaya mengikuti atau meniru budaya penutur asli. $^{23}$

Sebaliknya menurut Byram bahwa oleh karena banyak aspek dalam komunikasi non-verbal itu tidak disadari meskipun dipelajari dalam lingkungan budaya yang ada, pembelajar bahasa mungkin tidak mampu untuk mengon- trolnya, apalagi ingin untuk menunda apa yang sudah dirasakan sebagai bagian dari kepribadiannya, dengan harapan untuk memperoleh komunikasi non-verbal orang lain. Oleh karen itu yang penting sebenarnya adalah agar pembelajar mampu untuk melihat persamaan dan perbedaan dan membangun hubungan diantara sistem yang dimiliki dengan system orang lain dan bukan sekedar meniru-niru penutur asli. $^{24}$

Meskipun komunikasi non-verbal ini tidak menjadi kajian dalam tulisan ini, namun sangat erat kaitannya dengan kelancaran dalam berkomunikasi, oleh sebab itu kiranya hal ini dapat mendukung dalam pembelajaran bahasa fungsional. Sebab kelancaran berko- munikasi, seperti yang disinggung dimuka, bukan hanya ditentukan oleh penguasaan terhadap unsur-unsur linguistik (termasuk sosiolinguistik) semata, tetapi juga oleh unsur-unsur lain yang ada di luar bahasa. Dengan demikian tidak ada salahnya jika dalam pembelajaran bahasa Inggris di Sekolah Menengah Umum guru bahasa Inggris memberikan informasi mengenai masalah ini kepada para siswanya sebagaimana yang disarankan Payatos.

Kembali pada pokok persoalan, bahwa pada prinsipnya fungsi-fungsi umum bahasa seperti yang dijelaskan di atas seharusnya dikuasai oleh pembelajar bahasa Inggris di Indonesia, sebab

\footnotetext{
${ }^{23}$ Ibid., hal. 14

${ }^{24}$ Ibid.
}

fungsi-fungsi bahasa tersebut dirancang untuk kebutuhan tingkat ambang (threshold level). Sebab sebagaimana dikatakan SUS. Nababan bahwa "Dengan hubungan Internasional Indonesia yang makin luas, para lulusan Sekolah Lanjutan Atas seharusnya diperlengkapi dengan kemampuan BT hingga tingkat ambang agar cakrawala

ilmunya lebih luas.”25

Berdasarkan uraian di atas, maka dapat disimpulkan bahwa kemampuan menggunakan fungsi-fungsi bahasa seperti kemampuan seseorang untuk menggunakan bahasa sesaui dengan fungsi sosialnya. Artinya, seorang penutur bahasa, dalam hal ini bahasa Inggris, harus mendalami betul tata aturan sosial masyarakat penutur asli dalam menggunakan bahasa pertamanya. Dengan demikian pembelajar bahasa Inggris di Indonesia, khususnya pada tingkat SLTA, harus menguasai ungkapan-ungkapan komunikatif yang sesuai dengan kontek situasinya, kapan, di mana dan dengan siapa ia berbicara. Ungkapan bahasa fungsional yang harus dikuasai oleh pembelajar bahasa Inggris ini pada prinsipnya mengacu pada kebutuhan sampai tingkat ambang yang sudah dirumuskan oleh Dewan Eropa melalui klasifikasi yang berdasarkan analisis kebutuhan yang dibuat oleh Van Ek.

Tingkat ambang yang dimaksud di sini adalah tingkat keterampilan berbahasa minimal yang harus dikuasai orang supaya dapat survive di tempat di mana para penuturnya menggunakan bahasa tertentu sebagai alat komunikasi.

Kemampuan tingkat ambang merujuk pada kemampuan menggunakan fungsi - fungsi umum bahasa secara lisan. Jadi, tingkat keterampilan berbicara siswa Sekolah Lanjutan Atas akan ditentukan oleh kemampuannya menggunakan fungsi-fungsi bahasa sampai pada tingkat ambang ini.

\footnotetext{
${ }^{25}$ SUS. Nababan, Metodologi Pengajaran Bahasa (Jakarta: PT. Gramedia, 1989), hal. 90.
} 


\section{Penutup}

Salah satu aspek keterampilan berbahasa yang sangat penting peranannya dalam upaya menghasilkan generasi masa depan yang cerdas, kritis, kreatif, dan berbudaya adalah kete- rampilan berbicara. Dengan menguasai keterampilan berbicara (baca: komunikasi lisan), pembelajar bahasa akan mampu mengekspresikan pikiran dan perasaannya secara cerdas sesuai konteks dan situasi berbicara. Keterampilan berbicara juga akan mampu membentuk generasi masa depan yang kreatif sehingga mampu memproduksi tuturan atau ujaran yang komunikatif, jelas, runut, dan mudah dipahami. Selain itu, keterampilan berbicara juga akan mampu melahirkan generasi masa depan yang kritis karena mereka memiliki kemampuan untuk mengekspresikan gagasan, pikiran, atau perasaan kepada orang lain secara runtut dan sistematis. Bahkan, keterampilan berbicara juga akan mampu melahirkan generasi masa depan yang berbudaya karena sudah terbiasa dan terlatih untuk berkomunikasi dengan pihak lain sesuai dengan konteks dan situasi tutur pada saat berbicara.

Salah satu pendekatan pembelajaran yang dianggap mampu me- wujudkan situasi pembelajaran yang kondusif; aktif, kreatif, efektif, dan menyenangkan adalah pendekatan pragmatik. Melalui pendekatan prag- matik, pembelajar bahasa diajak untuk berbicara dalam konteks dan situasi tutur yang nyata dengan menerapkan prinsip pemakaian bahasa secara komprehensif.

Prinsip-prinsip pemakaian bahasa yang diterapkan dalam pendekatan pragmatik, yaitu (1) penggunaan bahasa dengan memperhatikan aneka aspek situasi ujaran; (2) penggunaan bahasa dengan memperhatikan prinsip-prinsip kesantunan; (3) penggunaan bahasa dengan memperhatikan prinsip-prinsip kerja sama; dan (4) penggunaan bahasa dengan memperhatikan faktor-faktor penentu tindak komunikatif. Melalui prinsip-prinsip pemakaian bahasa sema- cam itu, pendekatan pragmatik dalam pem- belajaran keterampilan berbicara diharapkan mampu membawa pembelajar bahasa ke dalam situasi dan konteks berbahasa yang sesungguhnya sehingga keterampilan berbicara mampu melekat pada diri mereka sebagai sesuatu yang rasional, kognitif, emosional, dan afektif.

\section{Daftar Pustaka}

Alwasilah, A. Chaedar, Linguistik Suatu Pengantar. Bandung: Angkasa, 1987.

Austin, John L. 1962. How to Do Things with Word (edisi kedua). Oxford: Oxfod University Press.

Brown, H. Doughlas, 1987. Principle of Language Learning and Teaching. USA.Prentice Hall, Second dition.

Brumfit, C.J., and Johnson, K. (Ed). The Communicative Approach to Language Teaching. London: Oxford University Press, 1983.

Byram, Michael. Teaching and Assessing Intercultural Communicative Competence. Great Britain: WBC Book Manufactures Ltd., 1997.

Chaer, Abdul. 1994. Pengantar Semantik Bahasa Indonesia. Jakarta: Rineka Cipta.

Cruse, Alan. 2000. Meaning in Language: an Introduction to Semantics and Pragmatics. New York: Oxford University Press.

Eelen, Gino. 2001. Critique of Politeness Theory. UK: Northampton, MA: St.Jerome.

Gunarwan, Asim.. Pragmatik, Teori dan Kajian Nusantara. Jakarta: Univ. Atmajaya Press, 2007..

Kurikulum Bahasa Inggris Tahun 2004 untuk SD, SMP, dan SMA.

Levinson, S. C. 1983. Pragmatics. Cambridge: Cambridge University Press.

Nababan SUS, Metodologi Pengajaran Bahasa. Jakarta: PT. Gramedia, 1989.

Schffin, Deborah.1994. Approach to Discourse. Cambirdge: Blackwell Publisher.

Sudiati V.dan A. Widyamarta, 1996. 
Kreatif Berbahasa Menuju Keterampilan Pragmatik Yoyakarta: Kanisius.

Thomas, Jenny. 1995. Meaning in Interaction: an Introduction to Pragmatics. London/New York: Longman.

Yule, George. Pragmatics. 1996.

Oxford: Oxford university Press.

http://ramlannarie.wordpress.com/2010/0

5/30/linguistik-pragmatik/

http://www.mindtools.com/pages/articles

newCs 99

http://umpress.um.edu.my/index.php?pro

ductID $=587$

http://susandi.wordpress.com/seputar- baha$\underline{\mathrm{sa} / \text { semantik/ }}$ 